\title{
Amylase Production on Solid State Fermentation by Bacillus Spp
}

\author{
Salwa Elamin Ibrahim ${ }^{1}$, Hassan Beshir El Amin², Elmutaz Nasir Hassan", \\ Abdel Moneim Elhadi Sulieman ${ }^{3}$ \\ Deaprtment of Biology, Faculty of Education, University of ElGadarif, Khartoum, Sudan \\ ${ }^{2}$ Commission for Biotechnology \&Genetic Engineering, National Centre for Research, Khartoum, Suadn \\ ${ }^{3}$ Department of Food Science and Technology, Faculty of Engineering and Technology, University of Gezira, Wad Medani, Sudan
}

\begin{abstract}
Twenty bacterial isolates were isolated from different sources. Preliminary screening for amylotic bacteria was performed on starch solid media. Out of them; 11 isolates showed positive results when flooded with iodine solution. The amylotic activity index was 93, 95 and 99. Identification of all isolates revealed that they belonged to the genus Bacillus. Out of all, three strains of Bacillus designated as B1, B2, and B11 were chosen for further study; according to their saccharification activity measured with the DNS method. Optimum conditions for enzyme production were measured, using wheat bran solid state fermentation (SSF) method. The optimum conditions for the three strains were generally found to be $55 \%$ $75 \%$ moisture contents ; not less than $48 \mathrm{hrs}$ incubation time ( 72 hours max. ); maximum enzymes production was attained at incubation temperature of $30^{\circ} \mathrm{C}-50^{\circ} \mathrm{C}$; although the amylase retained more than $89 \%$ of its activity at temperature ranging from $20^{\circ} \mathrm{C}-70^{\circ} \mathrm{C}$, and optimum $\mathrm{pH}$ of 3.5.Qualitative analysis revealed that glucose and maltose was produced by Bacillus strains, B11 enzymes from hydrolysis of soluble starch.
\end{abstract}

Keywords Fermentation, Flour, Microbiology, Starch, Wheat

\section{Introduction}

Amylases are one of the main enzymes used in industry. Amylases have been reported to occur in micro-organisms, although they are also found in plants and animals. Two major classes of amylases have been identified in micro-organisms, namely $\alpha$-amylase and glucoamylase. $\alpha$-Amylases (endo-1, 4- $\alpha$-D-glucan glucohydrolase, E.C. 3.2.1.1) are extracellular enzymes that randomly cleave the 1, 4- $\alpha$-D- glucosidic linkages between adjacent glucose units in the linear amylose chain. Glucoamylase (exo-1, 4- $\alpha$-D-glucan glucanohydrolase, E.C. 3.2.1.3) hydrolyzes single glucose units from the non-reducing ends of amylose and amylopectin in a step-wise manner[1].

A large number of microbial $\alpha$-amylases have applications in different industrial sectors such as food, textile, paper and detergent industries. The production of $\alpha$ amylases has generally been carried out using submerged fermentation, but solid state fermentation systems appear as a promising technology[2]. .

Solid state fermentation (SSF) is defined as the cultivation of micro-organisms on moist solid supports, either on

* Corresponding author:

moneim_ug@yahoo.com (Abdel Moneim Elhadi Sulieman)

Published online at http://journal.sapub.org/fph

Copyright (C) 2012 Scientific \& Academic Publishing. All Rights Reserved inert carriers or on insoluble substrates that can, in addition, be used as carbon and energy source. The fermentation takes place in the absence or near absence of free water, thus being close to the natural environment to which micro-organisms are adapted[3]. Many substrates have been used, wheat bran however, holds the key and has most commonly been used, in various processes[4]. Fungal and bacterial amylases could be potentially useful in the pharmaceutical and fine-chemical industries. However, with the advances in biotechnology, the amylase application has expanded in many fields such as clinical, medicinal and analytical chemistry, as well as their widespread application in starch saccharification and in the textile, food, brewing and distilling industries. Microbial enzymes are becoming increasingly important for their technical and economical advantages with annual growth rate of about $3.3 \%$.

Sudan is a tropical country with agriculture-based economy, and most of its population engaged in arable farming. The ability to upgrade the agricultural products could have considerable economic significance. The development of starch-based industry is one option. This, however, requires the presence of starch degrading enzymes of potential industrial applications. Despite this fact there was only a limited work in searching for microbial starch degrading amylases. The objectives of this work were therefore to isolate amylase producing bacterial strain/s from the environment under solid state fermentation (SSF) using agricultural 
by-products (wheat bran), to optimize both conditions for microbial enzymes cultivation and activity and to characterize the bacterial amylases and to determine their Potential application

\section{Materials and Methods}

\subsection{Screening of Amylotic Microbes}

Fifteen samples were collected from soils and starchy material (grain). Nutrient agar medium was inoculated with $2.0 \mathrm{ml}$ of $10 \%(\mathrm{w} / \mathrm{v})$ soil or sorghum flour suspension and incubated at $37^{\circ} \mathrm{C}$ for 48 hours. To obtain axenic culture ; a loop full was streaked onto the nutrient agar media. Pure isolates were preserved onto nutrient agar slants at $\pm 40 \mathrm{c}$ \pm for further studies.

\subsection{Potential Microbes for Production of Amylase}

According to the method of Qadeer,[5], starch agar media (g / L): Tryptone 10.0; soluble starch 3.0; $\mathrm{KH}_{2} \mathrm{PO}_{4}$ 5.0; yeast extract 10.0; and agar 15.0 was prepared and gram's iodine $(0.4 \% \mathrm{KI}+0.2 \% \mathrm{I} 2$ was also prepared. starch medium was sterilized at $121 \mathrm{oC}$ for 15 minutes.

Starch agar media were inoculated with isolated bacteria and incubated at $37^{\circ} \mathrm{C}$ for 48 hours. The Petri dishes were flooded with $5.0 \mathrm{ml}$ of iodine solution. The clear zone surrounding the colony was measured in $\mathrm{mm}$ from the edge of the colony to the limit of clearing and also the diameter of colony was recorded. The relative amylotic activity of isolates is expressed as an index of activity calculated as follows:

Amylotic activity index for microorganisms

$=\frac{\text { Average diameter of clear zone }- \text { Average diameter of colony }}{\text { Ave }}$ Average diameter of colony

\subsection{Identification of Bacteria}

The identification of purified isolates was carried out.

\subsection{Enzyme Production}

Enzyme production was done according to the method of (Hankin and Anagnostakis[6].

\subsection{Inoculums Preparation}

Different bacterial suspension $(1 \mathrm{ml})$ was prepared to inoculate a $100 \mathrm{ml}$ suspension of wheat flour $(5 \mathrm{~g} / 100 \mathrm{ml})$ after sterilization at $121^{\circ} \mathrm{C}$ for 15 minutes. The cultures were shaken on rotary shaker over night at room temperature. From this $5 \mathrm{ml}\left(7.0^{*} 10^{10} \mathrm{cfu}\right)$ were used as starter in the following experimental work..

\subsection{Wheat bran culture (Koji) Physiochemical Optimization under Solid State Fermentation Technique}

It was carried out in 1LErlenmeyer flask containing 50 grams of wheat bran moistened with $50 \mathrm{ml}$ different diluents $v i z$; tap water; $0.5 \mathrm{~g}$ peptone, $0.2 \mathrm{~g} \mathrm{~K}_{2} \mathrm{HPO}_{4}, 0.25 \mathrm{~g}$ yeast extract, $0.1 \mathrm{~g} \mathrm{MgSO}_{4} \cdot 7 \mathrm{H}_{2} \mathrm{O}$. the $\mathrm{pH}$ of the diluents was maintained at 7 with $1 \mathrm{~N} \mathrm{HCl} / \mathrm{NaOH}$.After the initial experiment distilled water was used throughout.

Different cultural conditions like moisture level $(40 \%, 45 \%, 50 \%, 55 \%, 60 \%, 65 \%, 70 \% 75 \%, 80 \%$ and $90 \%)$ different incubation period $(0,24,36,48,60,72,84,96$ and $120 \mathrm{~h}$ ), incubation temperature $\left(10^{\circ} \mathrm{C} 20^{\circ} \mathrm{C} 30^{\circ} \mathrm{C}, 40^{\circ} \mathrm{C}, 50^{\circ} \mathrm{C}\right.$ and $\left.60^{\circ} \mathrm{C}\right)$; initial medium $\mathrm{pH}(3.5,5.5,6,6.5,7,5,8$, and 8.5 , were optimized for the production of $\alpha$-amylase from Bacillus strains. The moist bran medium was autoclaved at $121^{\circ} \mathrm{C}$ for 15 minutes and then spreaded over the inner surfaces of the flasks by vigorous shaking. The flasks were inoculated with $5 \mathrm{ml}$ bacterial suspension $\left(7.0^{*} 10^{10} \mathrm{cfu}\right)$ and then rotated on their side for incubation. After pre- determined cultural conditions; the fermented bran was removed from the flasks air-dried at room temperature and preserved in an aluminum foil.

\subsection{Enzyme Extraction}

Enzyme extraction was done according to the method of (Hankin \& Anagnostakis[6]. A ratio of 10.0 parts of $0.05 \mathrm{M}$-phosphate buffer ( $\mathrm{pH} 6.5$ ) to one part by weight (of the original dry wheat bran koji was used for enzyme extraction. The fermented bran was shaken on a rotary shaker for 60 minutes at room temperature. To this, wheat bran suspension was added $1.0 \mathrm{ml}$ of $20 \% \mathrm{CaCl}_{2} \mathrm{H}_{2} \mathrm{O}$ per 40.0 $\mathrm{ml}$ of phosphate buffer and the culture was shaken for another 15 minutes. The resulting extract was filtered through a fine muslin cloth and the filtrate thus obtained was centrifuged at $3000 \mathrm{xg}$ for 20 minutes. This culture filtrate was used as crude enzyme for further analysis.

\subsection{The Rate of Starch Hydrolysis (Dextrinization)}

Dextrinogenic activity (loss of the ability of the starch to bind to the iodine sol.) was measured with modification of the method described by Hernandez and Pirt[7], as follows: $2.5 \mathrm{ml}$ of $1 \%(\mathrm{w} / \mathrm{v})$ soluble starch in phosphate buffer, $\mathrm{pH}$ 6.0 , were mixed with $0.5 \mathrm{ml}$ of enzyme solution, and incubated at $37^{\circ} \mathrm{C}$ for 15 minutes. The reaction was stopped by boiling in water bath for $2 \mathrm{~min}$. A sample $(0.5 \mathrm{ml})$ from each reaction tube was mixed with $1.0 \mathrm{ml}$ of iodine solution and $2.0 \mathrm{ml}$ distilled water, allowed to stand for 15 minutes at $37^{\circ} \mathrm{C}$. The colour intensity that developed was measured at $620 \mathrm{~nm}$. One unit of amylase activity was defined as the amount of enzyme that reduced iodine-starch colour by $1 \%$. at $37^{\circ} \mathrm{C}$ in one $\min [8]$. Reduction values were calculated by the following formula: color reduction $\%=\left\{{ }^{\mathrm{ODt} 1}\right.$ minus $\left.\mathrm{ODt} 2 / \mathrm{OD}_{0}\right\}$ * 100$\}$. Where : OD =Iodine-starch-enzyme ; solution boiled immediately before the addition of the enzyme OD15= the OD readings of the starch -enzyme solution after $15 \mathrm{~min}$.

\subsection{Amylase Enzyme Assay}

Amylase activity was determined by incubating mixture of $0.5 \mathrm{ml}$ aliquot each of enzyme source and $1 \%$ soluble starch dissolved in $0.1 \mathrm{M}$ sodium acetate buffer, $\mathrm{pH} 5$ at $37^{\circ} \mathrm{C}$ for $15 \mathrm{~min}$ [9]. The reducing sugar released after $15 \mathrm{~min}$ was measured by the method of Alkando[10]. One 
unit (IU) of amylase activity is defined as the amount of enzyme that releases $1 \mu \mathrm{mol}$ of reducing sugar as glucose, per minute, under assay conditions and expressed as $\mathrm{U} / \mathrm{g}$ of dry substrate (gds) the percent moisture content was calculated by the following formula $\%$ moisture content (initial) of solid medium $=($ wt. of the wheat bran - dry wt. $) \times 100 /$ dry wt[11].

\subsection{Quantitative Detection of B11 Amylase Activity on Starch (Paper Chromatography Method)}

Paper chromatography method was carried out for quantitative detection of sugars[11] as follows: Filter paper (What man No 5.0) was used. A reaction mixture of $2.0 \mathrm{ml}$ $1 \%(\mathrm{w} / \mathrm{v})$ starch in phosphate buffer $\mathrm{pH} 6.0$ and $1.0 \mathrm{ml}$ crude enzyme were incubated at $37^{\circ} \mathrm{C}$ for 1 hour. From each reaction mixture $50 \mu \mathrm{L}$ were spotted in portions on the paper and beside these reaction spots were spotted similar quantities of $0.02 \%(\mathrm{w} / \mathrm{v})$ glucose and maltose. After drying, the paper was developed in solvent mixture composed of nbutanol: acetic acid: water in a ratio of 6: $3: 1$ in a chromatographic tank. When the front of the solvent reached nearly the top of the paper; the paper was taken out and dried in air. The paper was first passed rapidly through a reagent solution of $0.1 \mathrm{ml}$ saturated aqueous silver nitrate solution in $20.0 \mathrm{ml}$ acetone. After drying in air, it was sprayed with alcoholic sodium hydroxide solution $(0.5 \mathrm{~N}$ solution of sodium hydroxide in aqueous ethanol) and finally washed with $0.5 \mathrm{M}$ sodium trio- sulphite solution to remove the brown silver oxide background. Reducing sugars appeared as black or dark brown spots on white background.

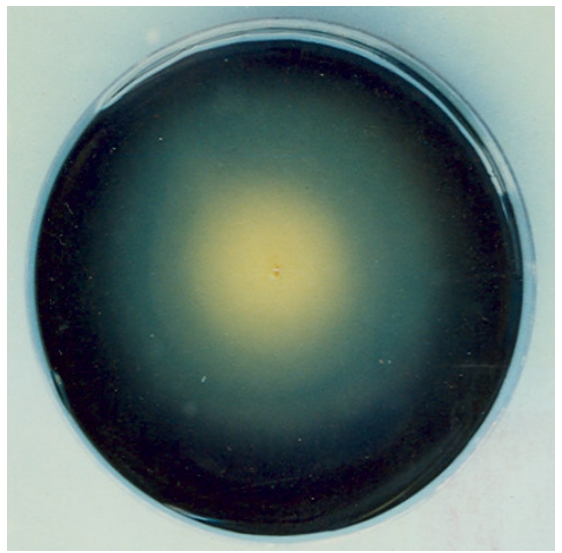

Plate 1. A starch agar plate showing amylase activity with clear white zone at the center surrounding the single colony of Bacillus Isolated from soil sample

\section{Results and Discussion}

Among 30 bacterial isolates from different sources, 10 were found to be positive amylotic producers as detected with iodine solution (Plate1.) Amylotic activity index ranged from 0.11 to 0.99 for the bacterial isolates presented in Table (1). Among these, three strains (B1, B2 \& B11) were selected for further studies. According to Ramesh and Lonsane[12], twenty bacterial strains producing amylases were isolated from Khartoum State; most of them were belonging to the genus bacillus which is considered to be the most important source of microbial enzymes[1]; an indication of the excellent microbial biodiversity in Sudan.. This genus contains Bacillus lichenifomis, capable of producing a thermos- table \& thermo-tolerance alpha-amylases[8].

Fig.1 depicts the effect of addition of some nutrients to improve amylase production; it seems that addition of other sources of nutrients had no effect on enzymes production Wheat bran however holds the key, and has most commonly been used, in various processes. Similar results were obtained[13];[14].

Table 1. amylotic Bacteria isolates

\begin{tabular}{cccc}
\hline $\begin{array}{c}\text { Bacterial } \\
\text { isolates }\end{array}$ & Source & Clear zone & $\begin{array}{c}\text { Amylotic } \\
\text { activity index } \\
*\end{array}$ \\
B1 & (Fetareta )flour Sorghum & +++ & 0.93 \\
B2 & Sorghum flour & +++ & 0.95 \\
B3 & Fermented flour & ++++ & 0.91 \\
B4 & clay Soil & ++ & 0.55 \\
B5 & Sorghum grain & ++ & 0.66 \\
B6 & loamy Soil & ++ & 0.55 \\
B7 & Soil & +++ & 0.84 \\
B8 & maize flour & ++ & 0.69 \\
B9 & Sand Soil & + & 0.22 \\
B10 & Maize & + & 0.33 \\
B 11 & mixed Soil & + & .99 \\
\hline
\end{tabular}

$(+++)$ high amylotic $;(++)$ medium amylotic; $(+)$ weak amylotic

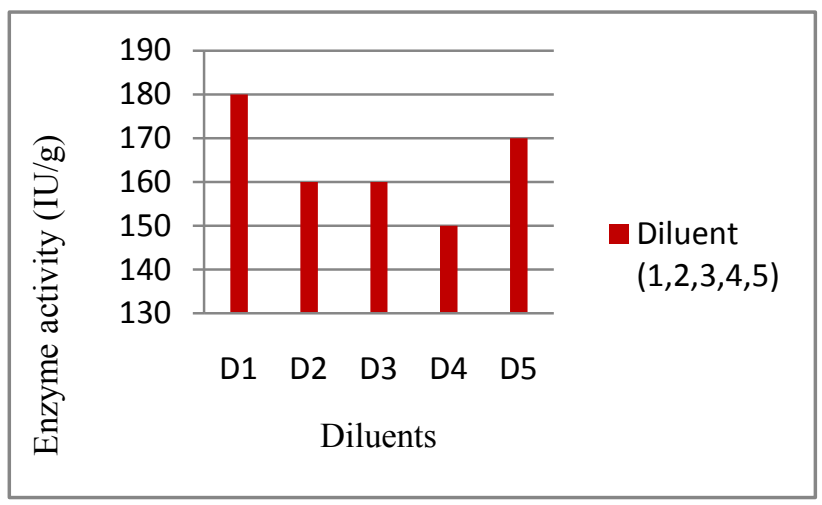

Figure 1. The Effect of addition of different nutrients

$\mathrm{D} 1=\mathrm{WB} *$ (wheat bran) $+\mathrm{DW}^{* *}($ Distilled water $)$

$\mathrm{D} 2=\mathrm{WB}+\mathrm{K} 2 \mathrm{HPO} 4(4 \mathrm{~g} \backslash \mathrm{L}) * * *$

$\mathrm{D} 3=\mathrm{WB}+\mathrm{K} 2 \mathrm{HPO} 4+$ Peptone $(10 \mathrm{~g} \backslash \mathrm{L}) ; * * *$

$\mathrm{D} 4=\mathrm{WB}+\mathrm{K} 2 \mathrm{HPO} 4+$ Peptone + Yeast extract $(5 \mathrm{~g} \backslash \mathrm{L}) * * *$

$\mathrm{D} 5=\mathrm{WB}+\mathrm{K} 2 \mathrm{HPO} 4+$ Peptone + Yeast extract $+\mathrm{MgSO} 4(2 \mathrm{~g} \backslash \mathrm{L}) * * *$

$* *$ Wheat bran $=50 \mathrm{~g}, * * \mathrm{DW}=50 \mathrm{ml}, * * \mathrm{DW}=50 \mathrm{ml}, * * *($ all nutrients were dissolved in $50 \mathrm{ml} \mathrm{DW}$ )

\subsection{Effect of Moisture Levels on Amylase Production}

As seen in Fig. (3) the optimum moisture content was in the range of $45 \%$ to $70 \%(1: 1.5-1: 2.5)$ for all strains tested. These results were in agreement with those of Lonsane[15], (1985). The moisture content is an important factor that influences the growth and product yield in SSF. Moisture is reported to cause swelling of the substrates, thereby facilitating better utilization of the substrate by micro-organisms, 
clearly indicates that the yield of amylopullulanase by $C$. thermosulfurogenes SVM1increased with an increase in solid to moistening agent ratio from 1:0.5 to $1: 2.5$ (30\% to $75 \%)$ with a maximum at $1: 2.25(73 \%)$. Any further increase in the ratio resulted in power enzyme production. The decrease of enzyme yields may be due to clumping of solid particles which results in the decrease of antiparticle space leading to decreased diffusion of nutrients[16]. In contrast, the low moisture content leads to the decreased solubility of nutrients present in the wheat bran there by decreases enzyme yields known to offer many advantages over submerged fermentation leading to overall reduction in the cost of production[16] and the products obtained by SSF are many folds higher than those obtained in submerged cultivation. In addition, the products obtained have slightly different properties (e.g. more thermo-tolerance) when produced in solid- state.

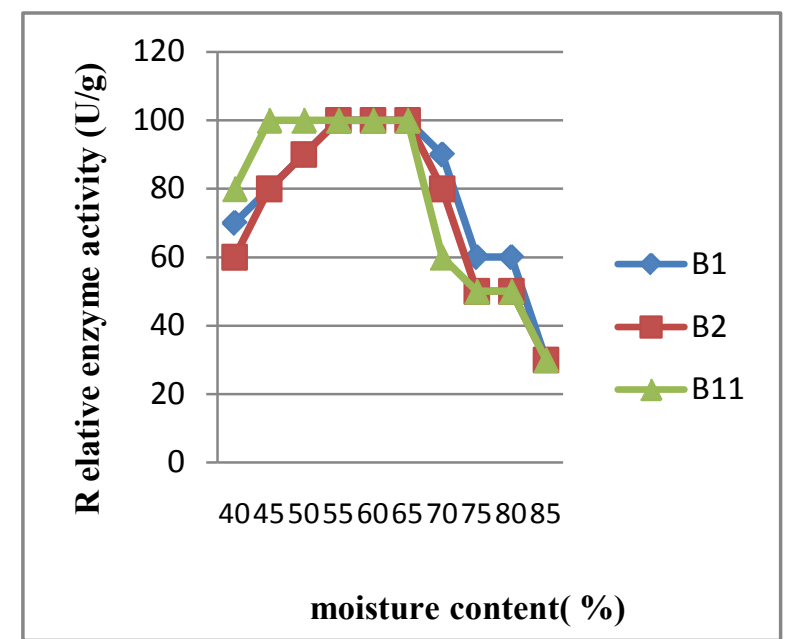

Figure 2. Effect of moisture content (\%) on different bacterial enzyme production

\subsection{Time Course of Enzyme Production}

Maximum enzyme production was affected by different koji incubation times $(24,48,72,96$ hours).Fig. 3 shows enzymes activity of different Bacillus strains B1, B2and B11. The results obtained show that all Bacillus strains had an upper level of activity after 48 hours incubation. The results indicate that further incubation did not show any increase in activity by Bacillus strains. Similar results were obtained by Ramesh and Lonsane[12] concluding that alpha-amylase appeared to be growth related (in starch media) since the cell mass growth kinetics as exactly similar to the enzyme production rate. Cell mass was also increased up to $72 \mathrm{hrs}$, then decreased along with cell growth; the results suggested that enzyme production has direct relationship with cell growth[17]. However, maximum amylase enzyme production was observed after $72 \mathrm{~h}$.and decreased thereafter

\subsection{Effect of Cultivation Temperature}

Optimum production of enzyme was effected by incubation at different temperatures $20^{\circ} \mathrm{C}-60^{\circ} \mathrm{C}$. The results in Fig.
(3) indicate that incubation temperature of $40^{\circ} \mathrm{C}$ was found to be the best for enzymes activity of all Bacillus strains B1, B2 and B11 However, all enzymes could be produced in incubation temperature of $50^{\circ} \mathrm{C}$; however, at $20^{\circ} \mathrm{C}$ the production of enzymes attained $40 \%$. The optimum temperature was observed for the production of -amylase from Banana stalk using $B$. subtilis was also $35^{\circ} \mathrm{C}$. Maximum amylase production was noticed when the incubation temperature of the medium was adjusted at $37^{\circ} \mathrm{C}$ or more. It might be due to the fact that $25^{\circ} \mathrm{C}-42^{\circ} \mathrm{C}$ is considered the national and optimal temperature of growth of most bacterial culture in Sudan; and subsequently for enzyme production. In addition, high temperature might have reduced the moisture contents of the fermentation medium and growth of the organism resulting in the decreased enzyme.

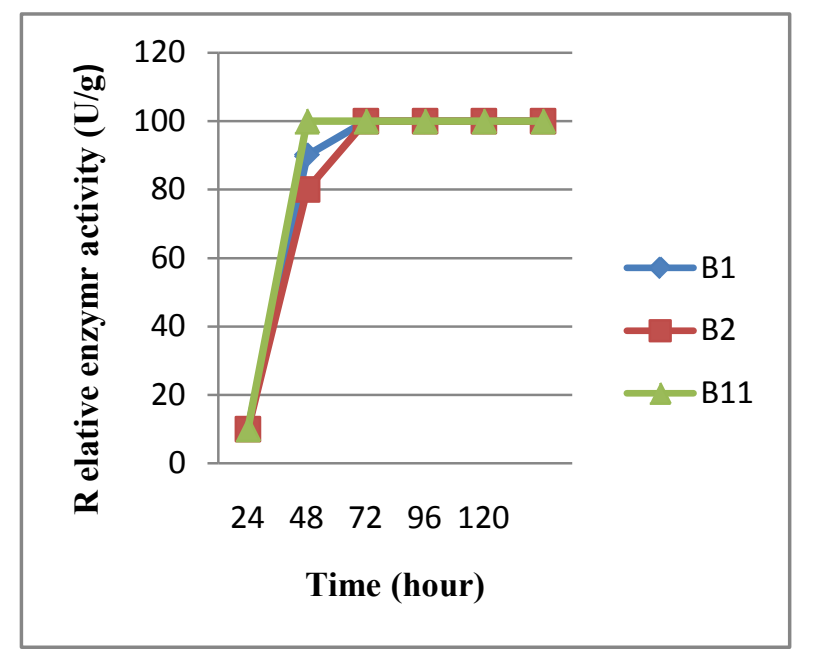

Figure 3. Effect of Time course on different bacterial enzyme production

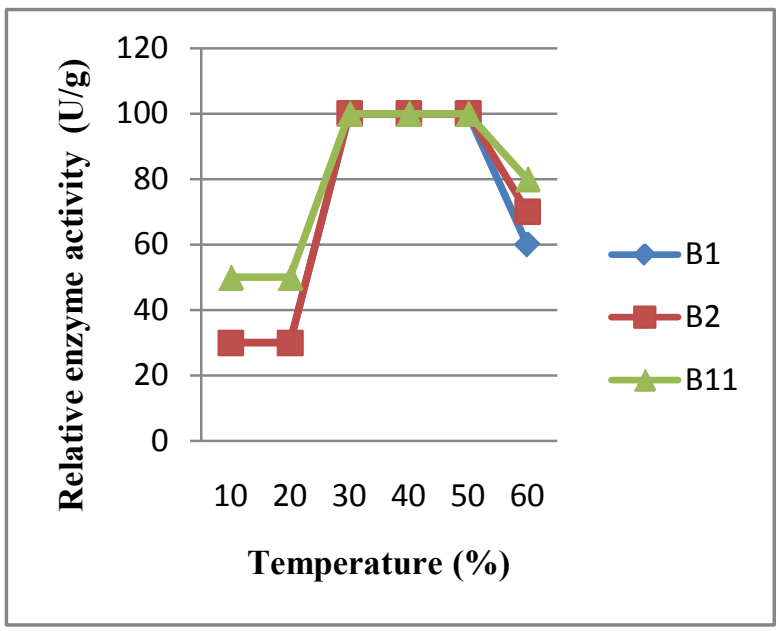

Figure 4. Effect of different incubation temperature on different bacterial enzyme production

\subsection{Effect of pH on Amylase Activity and Stability}

Influence of $\mathrm{pH}$ on the enzyme activity ( $\mathrm{pH}$ profile) is shown in Fig. 4. The $\mathrm{pH}$ profile of ese enzyme shows a very broad $\mathrm{pH}$ range of the activity at room temperature, so that it has the $90 \%$ of at $\mathrm{pH} 4.0-6.0$. The reported_amylases pro- 
duced by several bacterial sources, including Bacillus sp., has a variety of $\mathrm{pH}$ profiles. The maximum activity of the most of these earlier reported enzymes is in its maximum activity in the range of $\mathrm{pH} 3.5-7.0$ with its optimum $\mathrm{pHs}$ range of $\mathrm{pH} 6.0-8.0^{]}$or $\mathrm{pH} 5.0-7.0[19]$. In spite of earlier reports on the activty at low $\mathrm{pH}$ for some -amylases,such as those produced by Bacillus subtilis X-23[1] and Lactobacillus manihotivorans LMG 18010T 18], there are few reports on _-amylases which have the maximum activity at $\mathrm{pH}$ lower than 4.0. For example, the _-amylase produced by Alicyclobacillus acidocaldarius has the maximum activity at $\mathrm{pH} 3.0$ and one by Pyrococcus furiosus has about $70 \%$ of its maximum activity at $\mathrm{pH} 3.5$ without a wide $\mathrm{pH}$ is known to affect $\mathrm{pH}$ the synthesis and secretion of a-amylase just like its stability.

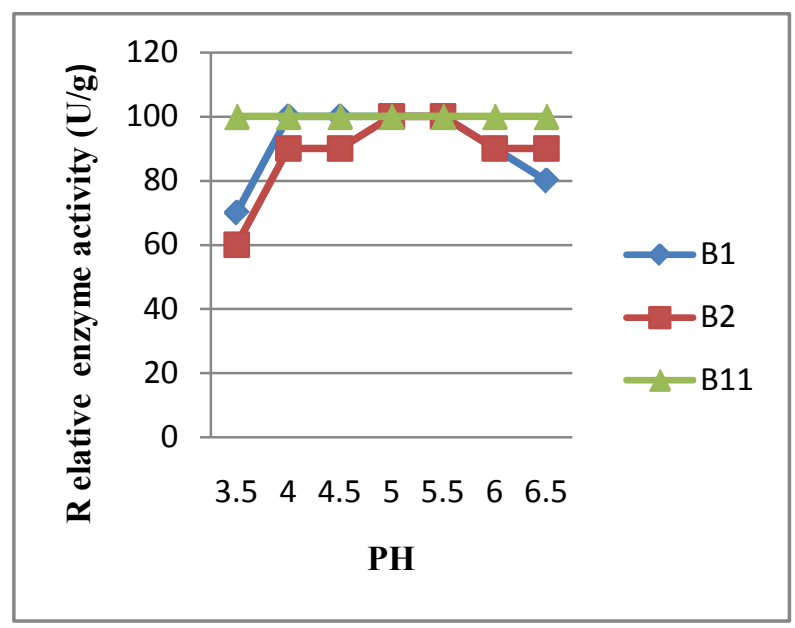

Figure 5. Effect of initial PH on different bacterial enzyme production

Optimum production of enzyme was affected by different initial $\mathrm{pH}$ levels (3.5 thro. 8,). The activity of different Bacillus strains shows that the $\mathrm{pH} 3.5-7.5$ was found to be the best for all the Bacillus strains. However, the $\mathrm{pH}$ of the fermentation medium was found to be optimum at 7.0. When $\mathrm{pH}$ is altered below 3.5 or above 7.5 is decreased or becomes denatured. Different organisms have different $\mathrm{pH}$ optima the optimum and decrease or increase in $\mathrm{pH}$ on either side of the optimum value results in poor microbial growth..In our study the amylase production by Bacillus spp. was found to be maximum at $\mathrm{pH}$ 4-7. Optimum at $4.0-6.0$. When $\mathrm{pH}$ is altered bellower above the optimum the activity is decreased or becomes denatured. Different organisms have different $\mathrm{pH}$ optima and

\subsection{Identification of the Hydrolytic Products of Soluble Starch}

The hydrolysis products obtained after treatment of soluble starch with the Bacillus strains B1, B2, B11 enzymes are shown in plate No (1). Glucose and maltose were used as standard to compare the hydrolysis products that are produced by treatment of soluble starch with the Bacillus strains enzymes. The result indicates that, glucose and maltose was produced by Bacillus strains B1, B2, B11 enzymes.
Since we used crude amylase, these results could be explained by the fact that there are about 14 amylases families producing different oligosaccharides.

Fig. (6) depicts qualitative soluble starch hydrolysis rate of different bacterial strains.StrainB1 and B2 had the same pattern of hydrolysis rate;did not reach the a chromic point, while B11reached it in $20 \mathrm{~min}$. an indication of the presence of different amylotic enzymes. Final product yields and substrate conversions were the only criteria of performance in early commercial fermentations. As the technology developed, however, greater attention was paid to the time factors; "productivity and the average rate of product formation.

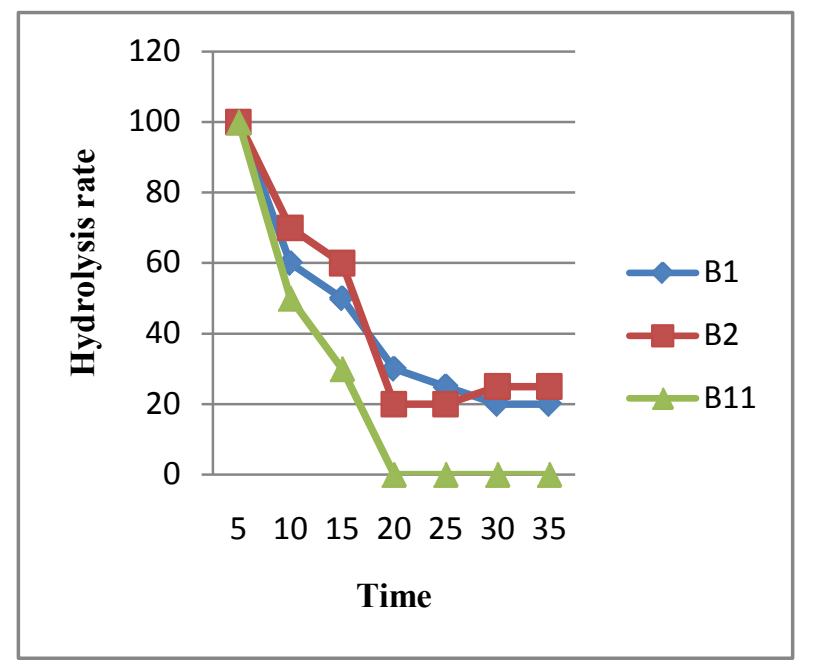

Figure 6. Starch hydrolysis rates by different bacterial enzyme( crude extract)

\section{Conclusions}

Some of the substrates that have been used world-wide included sugar cane bagasse, wheat bran, rice bran, maize bran, sorghum bran, wheat straw, sugar, sweet sorghum meal, cake, , wheat flour, corn flour, starch, etc.,. Wheat bran however holds the key, and has most commonly been used, in various processes. Since the enzymes of these strain has a broad $\mathrm{pH}$ range of activity, moderate thermo- stability, and appropriate temperature profile,\& could be produced on cheap substrates, therefore, it can be suitable candidate to be used as an additive for starch, biofuel and detergent industries. Due to the importance of our recent finding, further enzymatic studies on enzymes kinetics, structural analysis, and determination of encoded gene sequence of this amylase can be carried out.

\section{ACKNOWLEDGEMENTS}

The authors would like to express their thanks for Commission for Biotechnology and Genetic Engineering -National Centre for Research for their unlimited assistance during the research implementation 


\section{REFERENCES}

[1] Pandey, A.; Nigam, P.; Soccol, C.R.; Soccol, V.T.; Singh, D. and Mohan, R. (2000a). Advances in microbial amylases, Biotechnology and Applied Biochemistry, 31: 135 -152

[2] Monteiro de Souza, Paula and de Oliveira e Magalhães, Pérola. (2010).Application of Microbial $\alpha$-Amylase in Industry - A review. Brazilian Journal of Microbiology 41: 850- 861

[3] Pandey, A.; Soccol, C.R. \& Mitchell, D. (2000b). New developments in solid state fermentation. I Processes and products. Process Biochemistry, 35:1153-1169

[4] Pandey,A Selvakumar, P. Carlos R. Soccol* and Poonam Nigam(2001). Solid state fermentation for the production of industrial enzymes *Laboratorio de rocessos

[5] Qadeer, M.A.; Aurangzeb, M. \& Igbal, J. (1989). Production of raw starch hydrolyzing enzymes by mould cultures. Proceeding of the International Symposium on Biotechnology for Energy, Dec.16-21. Malik, K. A.; Nagvi, S.H. M. and Aleem, M.I. H. (eds.) Faisalabad, Pakistan, pp. 119-128

[6] Hankin, L. and Anagnostakis, S.L. (1975). The use of solid media for detection of enzyme production by fungi. Mycologia, 67:597 - 601

[7] Hernandez, E. \& Pirt, S.J. (1975). Kinetics of utilization of a highly polymerized carbon source (starch) in achemostat culture of Klebsiella aerogenes: Pullulanse and alpha- amylase

[8] Bajpai, P. and Bajpai, P. 1989. High-temperature alkaline a-amylase from Bacillus licheniformis TC RDC-B13. Biotecnologicos, Departamento do Engenharia Quimica,Universidade Federal do Parana, CEP81531-970, Curitiba-PR, Brazil

[9] Satyanarayana, T. (1994). Production of bacterial extracellular enzymes by solid-state fermentation, 122-129, In Pandey, A. (ed.) solid-state fermentation, Wiley Eastern Limited, New Delhi

[10] Alkando ,A . A , Elamin ,H . B, and Ibrahim, H . M. ( 2011).AThermostable Extracellular alpha-amylase from Bacillus Licheniformis Isolated from soil in Sudan . Sudan Academy of Science Journal (in Press )

[11] Ramesh, M.V. \& Lonsane, B.K. (1991). Regulation of alpha-amylase production in Bacillus licheniformis M 27 by enzyme end-products in submerged fermentation and its overcoming in solid state fermentation system. Biotechnology. Letter., Vol 13 LTO 5: 355-360

[12] Anto, Hema; Trivedi, Ujjval \& Patel, Kamlesh. (2006). $\alpha$-Amylase Production by B. cereus, Food Technology and Biotecholnology, 44 (2): 241-245

[13] Elmer. L. Gaden, Jr (1959) Fermentation Process Kinetics Journal of Biochemical and Microbiological Technology and Engineering. 1;(4.) 413-429. Laboratory, Thiruvananthapuram 695019 ,India $†$ School of Applied Biological and Chemical Sciences, University of Ulster, Coleraine BT52 $1 \mathrm{AS}, \mathrm{N}$. Ireland, UK

[14] Krishna, C. \& M. Chandrasekaran, 1996. fermentation and its overcoming in solid state Banana waste as substrate for "-amylase fermentation system. Biotechnol. Lett., Vol 13 LTO 5:production by Bacillus subtilis (CBTK-106) 355-360.under solid state fermentation. Appl. Microbiol 